\title{
Control of Key Maritime Straits - China's Global Strategic Objective
}

\author{
Dr. Alba Iulia Catrinel Popescu ${ }^{1}$
}

\begin{abstract}
:
On the $28^{\text {th }}$ of March 2015 the Chinese government published "Vision and Actions on Jointly Building the New Silk Road, The Economic and 21st - Century Maritime Silk Road"2.

This document signifies China's decision to become a global hegemon. With its issue this Chinese African - Eurasian "silk bridge" strategy redirected geopolitical analysts' attention away from another Beijing's strategic objective: control of key maritime straits, especially those featuring "maritime chokepoints", where concentrations of commercial and military naval routes flow.
\end{abstract}

Which are the main maritime straits covered by the Chinese "offensive"? What are the geostrategic implications of this approach?

Keywords: Belt and Road Initiative, China, maritime straits, maritime chokepoints, maritime hubs, oil traffic, global shores, hegemony.

\footnotetext{
${ }^{1}$ Academia Română - CRIFST, Bucureşti, albatanasescu@hotmail.com

${ }^{2}$ Vision and Actions on Jointly Building Silk Road Economic Belt and 21st-Century Maritime Silk Road, issued by the National Development and Reform Commission, Ministry of Foreign Affairs, and Ministry of Commerce of the People's Republic of China, with State Council authorization, March 2015, Xinhuanet, http://news.xinhuanet.com/english/china/2015. 03/28/c_134105858.htm, accessed at 10.02.2016.
} 


\section{Introduction}

China's bold hegemonically transformational project is officially entitled "Vision and Actions on Jointly Building the Silk Road Economic Belt and 21st-Century Maritime Silk Road", and publicly known as the Belt and Road Initiative. Drafted since March 2015, the document explains Beijing's aims to take greater control of global maritime spaces. In this regard, the project authors have identified two strategic axes that start in the South China Sea flowing to the Indian Ocean and to the Pacific Ocean respectively, which in combination are designed to create a maritime belt around Afro-Eurasia.

For this purpose, as described in the aforementioned strategy, China will implement a plan to secure shipping routes that will unite ports located on the route of the two axes, for the purpose of strengthening China - Pakistan. and China - Myanmar Bangladesh - India economic corridors. But this information and events in the South China Sea have redirected analysts' attention away from another Chinese global strategic objective represented by the silent economic conquest and military securing of maritime straits, especially of maritime chokepoints responsible for the overall management of naval, commercial and military flows and, in subsidiary, of the global shores. Which are the main maritime straits covered by the Chinese "offensive"? Which are the geostrategic implications of this approach?

\section{Which are the main global maritime straits characterized as chokepoints?}

A chokepoint is a marine area which causes natural maritime traffic congestion through a major strategic waterway. The geo-strategic and geo-economic values of chokepoints lie in the:

- $\quad$ economic consequences generated by their blockage, and forcing the use of alternative maritime routes, namely a considerable increase in distances, sailing duration, transportation costs and traded goods' costs, with impact on the suppliers and recipients economies (i.e. the price of oil, strategic minerals etc);

- bridgehead characterization involving, in case of taking them over by a hostile power, a significant allocation of resources and additional costs to remove her control and to resecure them for the use of all nations.

But there are other effects, too. Maritime congestion in subjacent maritime chokepoints entails increasing forms of crime at sea, from piracy to terrorism, followed by the exponential growth of vessels and cargo insurance policy costs. Therefore, controlling and securing the maritime chokepoints represent a strategic goal for every major geostrategic player. Globally, there are seven such major maritime chokepoints, namely:

- Danish straits - three in number (Storebælt, Lillebælt, Øresund), belong to Denmark, separating the Baltic Sea from the North Sea; 
- Malacca strait - between the Malay Peninsula and the island of Sumatra, separating the southern Indian Ocean from the Pacific Ocean;

- Strait of Hormuz - between Iran and the Arabian Peninsula (United Arab Emirates and Oman's Musandam enclave), that separates the Indian Ocean from the Persian Gulf;

- Bab el-Mandeb strait - between the Arabian Peninsula (Yemen) and the Horn of Africa (Djibouti and Eritrea), considered the gateway to the Gulf of Aden coming from the Indian Ocean;

- Suez Canal - between Port Said and Suez Gulf, belongs to Egypt and connects the Mediterranean Sea to the Gulf of Aden;

- Straits of Bosporus and Dardanelles - between the European and Asian Turkey, belong to Turkey and connects the Black Sea to the Mediterranean Sea;

- Panama Canal - belongs to Panama and connects the Atlantic and Pacific Oceans.

There are also, other four maritime straits with great geostrategic importance, namely:

- Bering Strait - between Alaska belonging to the US and Cape Dezhnev belonging to Russian Federation, separating the North Pacific Ocean from the Arctic Ocean. Its geostrategic value has significantly increased due to the melting of the Arctic ice cap and the creation, on a medium time horizon, of an arctic transport corridor;

- Gibraltar Strait - between the Iberian Peninsula and Africa (Morocco), separates the Mediterranean Sea from the Atlantic Ocean;

- Strait of Magellan (and Cape Horn) - between Chile and Tierra del Fuego (shared between Argentina and Chile), separates the Atlantic Ocean from the Pacific Ocean, it is the alternative route to the Panama Canal;

- Cape of Good Hope - Africa's South point, being the boundary between the Atlantic Ocean and the Indian Ocean, representing the alternative route to the Suez Canal.

It is important to mention that Cape Horn and the Magellan Strait, as well as the Cape of Good Hope maritime routes, are the only channels wide or deep enough for heavy tonnage vessels that exceed the dimensions of the Suez and Panama waterways.

To understand more clearly the impact of blocking these straits can be illustrated by analyzing global maritime oil traffic on daily basis. According to the US Energy Information Administration data, in the year 2013, over $50 \%$ of global oil was transported through maritime chokepoints. Of the 51.15 million barrels of oil transported daily, $33.2 \%$ representing 17 million barrels were transported through the Strait of Hormuz, 29.7\%, representing 15.2 million barrels were transported via the Strait of Malacca, the rest to $100 \%$ being transported around the Cape of Good 
Hope $-9.5 \%$, the Bab-el-Mandeb strait $-7.4 \%$, the Danish straits $-6.45 \%$, Suez Canal $-6.25 \%$, the straits of Bosporus and Dardanelles $-5.6 \%$ and through the Panama Canal $-1.66 \%$ (Figure 1).

Figure 1. Key global maritime chokepoints ${ }^{3}$

\section{Oil transit chokepoints}

About half of the world's oil production is moved by tankers on fixed maritime routes. The blockage of a chokepoint, even temporarily, can lead to substantial increases in total energy costs. Oil transit chokepoints are therefore a critical part of global energy security.

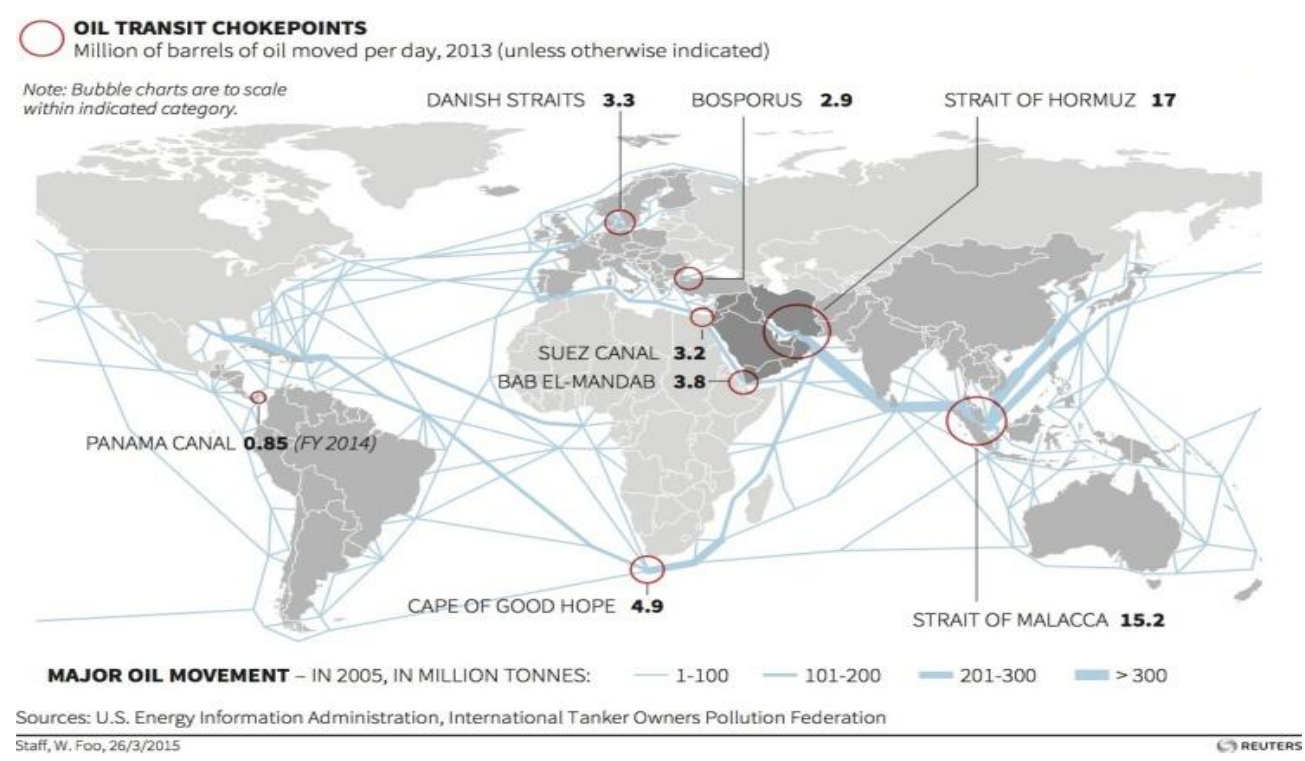

From the above data, the most congested maritime chokepoint is the Hormuz strait due to intense transit of oil tankers transporting crude oil from the Persian Gulf to global recipients. The second busiest maritime chokepoint is the Malacca Strait. Between $70-80 \%$ of the ships transiting that Strait have China as a starting point or destination ${ }^{4}$. Thus is explained China's critical interest in controlling the South China Sea. Oil tanker traffic to Far Eastern customers (China, Japan, South Korea etc), the narrowness of the waterway and the laced shoreline topography have turned the Malacca Strait into the new "pirate alley". According to the International Maritime Bureau of the International Chamber of Commerce, in 2014, there were

\footnotetext{
${ }^{3}$ Jeremy Bender, these 8 narrow chokepoints are critical to the world's oil trade, Business Insider, 01.04.2015, http://www.businessinsider.com/worlds-eight-oil-chokepoints-2015-4, accessed at 11.10.2016.

${ }^{4}$ Jiang Jie Bianji, China, Malaysia to build third port on Malacca, People's Daily Online, 05.07.2016, http://en.people.cn/n3/2016/0705/c90000-9081726.html, accesat la data de 20.10.2016.
} 
245 pirate attacks worldwide. Among these attacks 141 (57.55\%) occurred in SouthEast Asia while only 55 (22.44\%) occurred in African waters 5 .

Also, significant oil tanker traffic is registered through the Bab el-Mandeb Strait, the Gulf of Aden and the Suez Canal. Flanked by failed states like Somalia, Eritrea and Burundi on the one side and Yemen on the other side, Bab-el-Mandeb, with a width of only 18 nautical miles - $33.3 \mathrm{~km}$, and the Gulf of Aden were, until recently, the riskiest maritime destinations due to the increased incidence of pirate attacks and to the proliferation of terrorist networks. The risk of a regional security crisis and the impact upon Suez Canal maritime traffic forced the international community to intervene to secure the area.

Thus, in the last decade multinational military operations (NATO, EU and AU) ${ }^{6}$ and national (the Russian Federation, China and India) were held in the area in order to combat maritime piracy ${ }^{7}$ and terrorism. Subsequent to military interventions, starting with 2014, both maritime robbery and terrorist attacks of Al Shabaab and Al Qa'ida in the Arab Peninsula (the two most active Islamist organizations in the region) have considerably declined ${ }^{8}$. Regarding the Suez Canal, instability and the proliferation of Islamist movements' subsequent to Hosni Mubarak's regime fall in 2011, increased transiting vessels' security risk levels, as well the price of maritime insurance policies. The most secure maritime chokepoints are the Danish Straits, the Turkish Straits and the Panama Canal. The Danish Straits are the compulsory maritime shipping route for Russian oil. The Turkish Straits, whose narrowest point are but half a nautical mile $(.926 \mathrm{~km})$, facilitate the transit of Caucasian oil to global recipients. As for the Panama Canal, it allows North and South American oil to transit to Eurasian clients. The recent lifting of the ban on US crude oil and natural gas export ${ }^{9}$ will increase traffic through the Panama Canal (the first conclusive

${ }^{5}$ ICC International Maritime Bureau Piracy and Armed Robbery Against Ships -2014 Annual Report, REPORT FOR THE PERIOD 1 January - 31 December 2014, ICC International Maritime Bureau, January 2015, http://www.hellenicshippingnews.com/wpcontent/uploads/2015/01/2014-Annual-IMB-Piracy-ReportABRIDGED.pdf\#page =5\&zoom=auto,-107,513, accessed at 29.10.2015, p. 7 . ${ }^{6}$ Active Endeavour - NATO counter-terrorism operation in the Mediterranean Sea; Ocean Shield - NATO counter-maritime piracy operation in the Gulf of Aden, Red Sea and Indian Ocean; Atalanta - EU counter-maritime piracy operation in the Gulf of Aden, Red Sea and Indian Ocean; Enduring Freedom Horn of Africa - US counter-terrorism and countermaritime piracy in the Gulf of Aden area; AU lead ongoing counter-terrorism operation in Somalia, starting with September 2014.

${ }^{7}$ ICC International Maritime Bureau Piracy and Armed Robbery Against Ships -2014 Annual Report, op.cit., p.5

${ }^{8}$ Joint security update on Operation Indian Ocean by Somali Government and AMISOM, http://amisom-au.org/2014/10/joint-security-update-on-operation-indian-ocean-by-somaligovernment-and-amisom/, accessed at 20.10.2016.

${ }^{9}$ Brian Wingfield, US Crude Oil Export Ban, Bloomberg, 18.12.2015, https://www.bloomberg.com/quicktake/u-s-crude-oil-export-ban, accessed at 02.10.2016. 
statistics regarding the volume and destinations of US exported crude oil are expected later this year). Obviously, in these conditions a disruption of flows at any of the aforementioned maritime straits is automatically reflected in oil prices and, subsequently, the global economy. But, beside oil, other goods from liquefied gas and strategic minerals to all sort of commodities are transported through maritime chokepoints. For this reason, the control and security of maritime straits are imperatives for any major geopolitical player as the price of energy, food, technology security are directly connected to the permeability of these waterways.

\section{Which maritime chokepoints were the subjects of Chinese interest?}

\subsection{Indo Pacific area}

Information regarding Chinese plans to construct a string of 18 naval military bases along the southern shores of the Afro-Eurasian continental mass was originally unveiled in International Herald Leader, ${ }^{10}$ a newspaper affiliated to the Chinese national media agency Xinhua News Agency, on January 4, 2013. A year later, the American agency Stratfor published an analysis ${ }^{11}$ of the Chinese military plan in the Indo-Pacific area drawing additional public attention to the inclusion in this plan of three other South American states,: Argentina, Chile and Brazil (Figure 2).

Figure 2. Chinese Overseas Strategic Support Bases Plan ${ }^{12}$

PORTS USED FOR RESUPPLY IN CHINESE NAVAL DEPLOYMENTS

Established operational resupply nodes
Frequent visits/resupplies
Sparse or recently initiated visits

${ }^{10}$ Chinese paper advises PLA Navy to build overseas military bases, 08.01.2013, http://www.china-defense-mashup.com/chinese-paper-advises-pla-navy-to-build-overseasmilitary-bases.html accessed at 05.03.2016.

${ }^{11}$ Mapping China's Maritime Ambition, Stratfor, Stratfor, 23.11.2014, https://www.stratfor.com/analysis/mapping-chinas-maritime-ambition, accessed at 03.01.2016

${ }^{12}$ Mapping China's Maritime Ambition, op.cit. 
The 18 Overseas Strategic Support Bases, covered by the Chinese military plan are located in the following ports: Chongjin (North Korea), Moresby (Papua New Guinea), Sihanoukville (Cambodia), Koh Lanta (Thailand), Sittwe (Myanmar), Dhaka (Bangladesh), Gwadar (Pakistan), Hambantota (Sri Lanka), the Maldives, Seychelles, Djibouti (Djibouti), Lagos (Nigeria), Mombasa (Kenya), Dar es Salaam (Tanzania), Walvis Bay (Namibia ) and Luanda (Angola).

According to Stratfor the Chinese military plan, expected to be functional by the year 2023, provides three categories of Overseas Strategic Support Bases for ${ }^{\mathbf{1 3}}$ :

1. logistical support in peacetime : Djibouti, Aden (Yemen) and Salalah (Oman);

2. logistical support and warships docking, landing strips for aircraft and barracks: Seychelles;

3. military bases for large warships and barracks: Pakistan.

The naval military bases are designed to build three life lines in the:

$\checkmark$ Northern Indian Ocean: Pakistan, Sri Lanka, Myanmar;

$\checkmark$ Western Indian Ocean: Djibouti, Yemen, Oman, Kenya, Tanzania and Mozambique;

$\checkmark$ Central-Southern area of the Indian Ocean: Seychelles and Madagascar.

A brief review of this military plan's implementation phase reveals Beijing officials' determination not only to control the southern shore of Afro-Eurasia but additionally some of the most important maritime chokepoints, active in this region:

- North Korea - rental of Chongjin port ${ }^{14}$, starting with 2012, for a period of 30 years, for strictly economic purpose;

- Papua New Guinea - active involvement in the autonomous province of Bougainville ${ }^{15}$ referendum on independence planned for 2020. Bougainville is located next to the eponymous maritime strait;

- Indonesia - bilateral discussions regarding locations for a port on Sumatra and another one on Kalimantan ${ }^{16}$;

\footnotetext{
${ }^{13}$ Information already presented in Chinese "Belt and Road Initiative" - The Birth of a New Hegemony?, written in colaboration with Tiberiu Tanase and presented at Conferinţa Internaţionala „Ştiinţe Politice, Relaţii Internaţionale Şi Studii De Securitate” Ediţia A X-A, Sibiu, 27-29 Mai 2016.

${ }^{14}$ China gets 30-year lease on DPRK port, China.org.cn, 12.09.2012, http://www.china.org.cn/business/2012-09/12/content_26505704.htm, accessed at 03.01 .2016

${ }^{15}$ Could China be the catalyst for an independent Bougainville?, The Australian, 26.10.2015, http://asopa.typepad.com/asopa_people/2015/10/could-china-be-the-catalyst-for-anindependent-bougainville.html/, accessed at 02.03.2016

${ }^{16}$ Zuraidah Ibrahim, Indonesia to throw open doors to Chinese investment; seeks details on maritime Silk road, South China Morning Post, 25.03.2015, http://www.scmp.com/news/asia/article/1746628/widodo-aims-use-china-visit-boost-tiesand-seek-details-maritime-silk-road, accessed at 11.10.2016.
} 
- Myanmar - free stopovers (no limit of time) for Chinese commercial and military ships in the port of Yangon, since $2010^{17}$;

- Bangladesh - Chittagong port development works ${ }^{18}$;

- Pakistan - starting with April 2015, concession for the next 40 years of the Gwadar deep sea port, ideal for docking submarines ${ }^{19}$;

- Sri Lanka - Building artificial islands near Colombo, halted in 2015 by President's Maithripala Sirisena administration, following India's protests ${ }^{20}$

- Seychelles and Maldives Archipelagos - construction of Chinese naval military bases in the deep sea natural harbors to combat maritime piracy ${ }^{21}$;

- Gulf of Aden - free stopovers (no limit of time) for military and commercial ships in Chinese ports in Yemen and Oman since 2010²2,

- Tanzania - a China - Oman project of Bagamoyo port modernization and development into the largest maritime trade hub in East Africa ${ }^{23}$;

- Kenya - Lamu port and Mombasa port modernization. Lamu port hosts the headquarters of the LAPSSET pipeline maritime terminal that will serve Ethiopia, Uganda, South Sudan and Kenya ${ }^{24}$. Mombasa port is the largest port in the Horn of Africa;

- Mozambique - reconstruction of Beira fishing port and investments in infrastructure projects. Beira port is located inside the Mozambique Channel ${ }^{25}$;

- South Africa - under the current administration of South African President Jacob Zuma accelerated development of political, economic and military

\footnotetext{
${ }^{17}$ Mapping China's Maritime Ambition, op.cit.

${ }^{18}$ Asia Maritime Transparency Initiative, CSIS, http://amti.csis.org/indian-ocean/, accessed at 22.10.2015

${ }^{19}$ Asia Maritime Transparency Initiative, op.cit.

${ }^{20}$ Ibidem.

${ }^{21}$ Chinese President Xi highlights that common understanding and joint efforts have brought Sino-Maldives relations to the cusp of elevation to a higher plane. President Yameen thanks President Xi for positively considering his proposal to support the construction of the Male'Hulhule' Bridge, The President's Office, 15.09.2014, http://www.

presidencymaldives.gov.mv/Index.aspx?lid=11\&dcid=14821, accessed at 20.02.2016

${ }^{22}$ Mapping China's Maritime Ambition, op.cit.

${ }^{23}$ Arthur Chatora, Tanzania breaks ground on \$10bn China-Oman funded port, din sursa Reuters, 30.10.2015, http://thisisafrica.me/tanzania-breaks-ground-on-10bn-china-omanfunded-port-project/, accessed at 20.02.2016.

${ }^{24}$ George Mwangi, Chinese Firm Signs \$478.9 Million Kenya Lamu Port Deal, THE WALL STREET JOURNAL, 03.08.2014, http://blogs.wsj.com/frontiers/2014/08/03/chinese-firmsigns-478-9-million-kenya-lamu-port-deal//, accessed at 20.02.2016.

${ }^{25}$ China funds reconstruction of fishing port in Mozambique, macauhub, 11. 09.2014, http://www.macauhub.com.mo/en/2014/09/11/china-funds-reconstruction-of-fishing-port-inmozambiquel, accessed at 02.03.2016.
} 
cooperation $^{26}$ inside the institutional framework of the emerging powers organization BRICS $^{27}$ as well as in the particular, bilateral relationship;

- Namibia - discussions regarding the location of a military naval base in the deep sea port of Walvis Bay ${ }^{28}$;

- Angola - increasing presence of Chinese warships in the port of Luanda since $2013^{29}$ and major investments in the national economy;

- Nigeria - increasing presence of Chinese warships in the port of Lagos since 2013 and joint naval military exercises, in the Nigerian territorial waters in 2013 and $2014^{30}$, cooperation in the military field, as well as major investments in transport infrastructure and exploitation of hydrocarbon resources and mineral ores.

By superimposing maps shown in Fig.1 and Fig.2 we note the strategic location of these ports near some of the most important maritime chokepoints such as:

- Malacca Strait - Chongjin port in North Korea, Bougainville port in Papua New Guinea, Yangon port in Myanmar, future Sumatra and Kalimantan ports;

- Strait of Hormuz - Gwadar port in Pakistan;

- Bab el-Mandeb strait - Djibouti port, Kenyan Lamu and Mombasa ports, Tanzanian port of Bagamoyo;

- Gulf of Aden - Yemen and Oman ports;

- Cape of Good Hope - the Namibian port of Walvis Bay and Chinese South African cooperation on multiple levels.

These data should be read in conjunction with the territorial dispute in the South China Sea between China and the rest of the riparian states (Taiwan, Brunei, Malaysia, Vietnam and the Philippines). The dispute concerns sovereignty over the Spratly, Paracel and Natuna Islands, the territorial waters, exclusive economic zones and their related maritime boundaries in the Gulf of Tonkin.

\footnotetext{
${ }^{26}$ China is one of the main military partners of Algeria, Angola, Egypt, Ghana, Nigeria, South Africa, Sudan, Tanzania, Uganda, Zambia and Zimbabwe. See: China's role in Africa's conflicts: Military cooperation, arms transfers and involvement in peacekeeping operations, Consultancy Africa Intelligence,

14.04.2014,http://www.polity.org.za/article/chinas-role-in-africas-conflicts-militarycooperation-arms-transfers-and-involvement-in-peacekeeping-operations-2014-04-14, accessed at 02.03.2016

${ }^{27}$ BRICS is the acronym for Brazil, Russia, India, China and South Africa.

${ }^{28}$ Adam Hartman, Chinese naval base for Walvis Bay, The Namibian, 19.11.2014, http://www.namibian.com.na/ index.php?id=130693\&page=archive-read, accessed at 20.10.2015.

${ }^{29}$ Mapping China's Maritime Ambition, op.cit.

${ }^{30}$ Chinese, Nigerian Navies Conduct First-Ever Joint Military Exercise; Anti-Piracy Drills Underway, Beegeagle's blog, 29.05.2014, https://beegeagle.wordpress.com/2014/05/29/chinese-nigerian-navies-conduct-first-everjoint-military-exercise-anti-piracy-drills-underway/, accessed at 02.03.2016.
} 
Beijing's decision to build three artificial islands equipped with runways, ports and military bases in the Spartly Archipelago, followed by naval, terestrial and air interdiction of other riparian states from performing economic and military activities in the region, are based on a double stake:

1. economic - related to the right of ocean fishing, the right of hydrocarbon exploitation (11 billion barrels of oil and 190 trillion cubic meters of natural gas), sub-marine strategic minerals exploitation, and control of the trade routes passing through the region ${ }^{31}$;

2. strategic - control of maritime corridors that connect Southern and Northern Pacific Ocean, passing through Malacca chokepoint region.

Given the total volume of goods transiting the South China Sea worth \$ 5.3 trillion annually $^{32}$ even a temporary lock of the maritime corridors would result in major economic consequences worldwide. No - fly zones in the South China Sea are already affecting smooth running of military and civilian transit in the region, and China's sovereignty claims over Northern Pacific islands, disputed with Japan - the islands of Senkaku/Diaoyu as well as with Japan and South Korea - Socotra islands, generated re-balancing formulas through geopolitical axis such as US - Vietnam India, US -Taiwan - Japan -South Korea, US - Australia - New Zealand ${ }^{33}$.

The ports covered by the Chinese military plan target not only the major maritime chokepoints but also other straits that might otherwise become alternative routes should the main ones be blocked. In this respect, the main regions covered by the Chinese strategy are the Indonesian Archipelago and Malaysia, Philippine Archipelago, the island of Papua New Guinea, Australia, Andaman Archipelago, Malvinas Archipelago, Mozambique Channel, Zanzibar and Pemba straits.

1. Indonesia - contains a large number of side straits that can take over, if necessary, maritime traffic that might be diverted from the Strait of Malacca (see map in Figure 3$)^{34}$. Among these ones there are Bangka Strait - between the islands

\footnotetext{
${ }^{31}$ Territorial Disputes in the South China Sea, Council on Foreign Relations, http://www.cfr.org/global/global-conflict-tracker/p32137\#!/conflict/territorial-disputes-inthe-south-china-sea, accessed at 02.03.2016

${ }^{32}$ Territorial Disputes in the South China Sea, op.cit.

${ }^{33}$ Ibidem.

${ }^{34}$ Namely: the Strait of Alor - between archipelago Solor and Archipelago Alor, Bali Strait between the islands of Bali and Java, Gaspar Strait - between the islands of Belitung and Bangka, Lombok Strait - between the islands of Bali and Lombok (Java Sea), Madura Strait between the islands of Java and Madura, Manipal Strait - between the islands of Ceram and Buru, Mindoro Strait - between the islands of Mindoro and Palawan, Ombai Strait - between Alor Archipelago and the island of Wetar, Sumba Strait - between the islands of Flores and Sumba, Sunda Strait - between the islands Sumatra and Java, Indonesia Dampier Strait between Bird's Head peninsula and Raja Ampat islands, Wetar Strait - between Timor and Wetar island.
} 
of Sumatra and Bangka, Mentawai Strait - between the islands of Sumatra and Mentawai, Karim Strait - between the islands of Sumatra and Borneo (Kalimantan is the Indonesian part of the Borneo island), Singapore Strait - between Singapore and Sumatra and the Strait of Macassar - between the islands of Borneo and Sulawesi.

Figure 3. Political map of the Indonesian Archipelago and Malaysia ${ }^{35}$

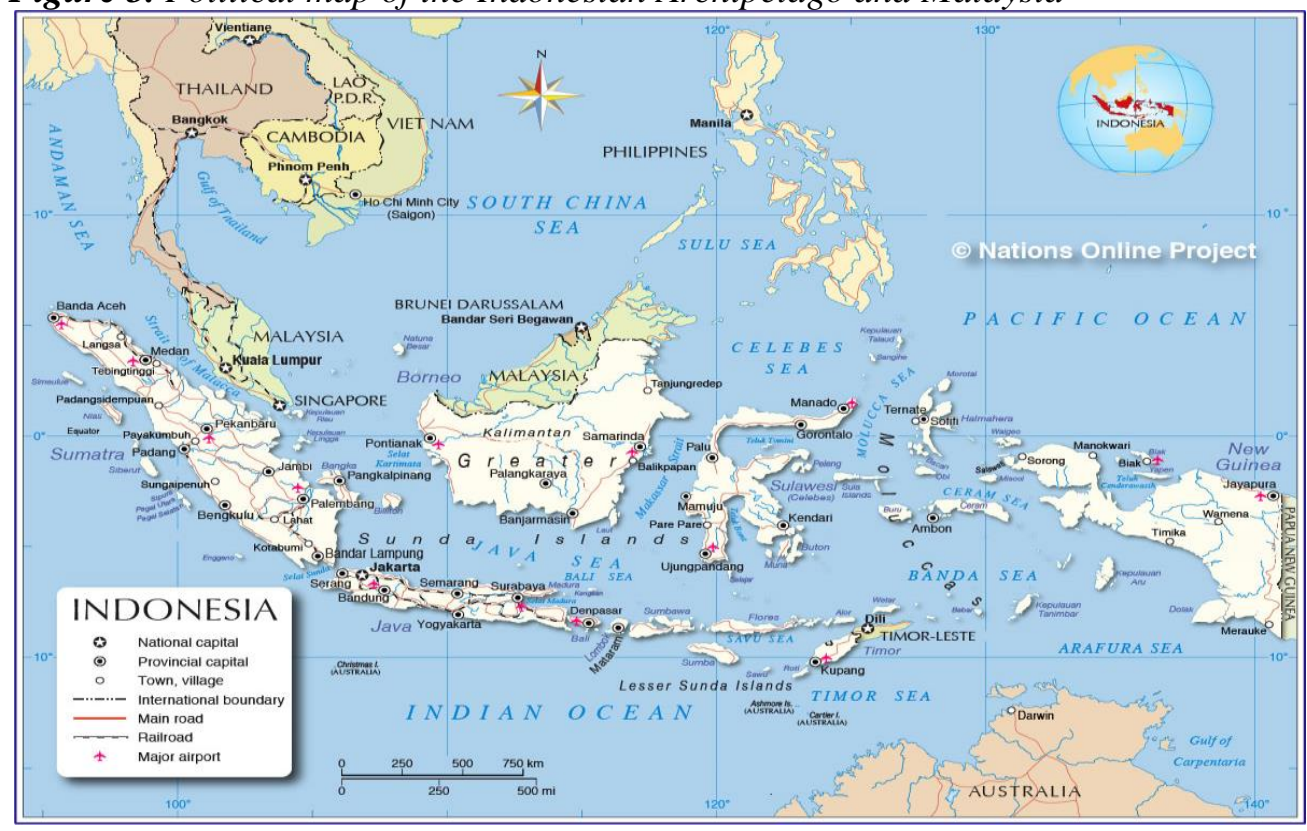

This is how Chinese naval base location in the islands of Sumatra and Kalimantan, for example, exert direct influence not only upon the Straits of Malacca but also on the rest of the region, as can be seen in Fig.2. Chinese military plans in Indonesian waters are supported by a strong community of Chinese nationals and companies operating in the region reunited in the so-called bamboo network ${ }^{36}$. According to the 2010 census, there are more than 2.8 million Chinese living in the Indonesian Archipelago, representing $1.2 \%$ of the total population of the country ${ }^{37}$. But unofficial sources claim that the number of ethnic Chinese living in Indonesia would reach between 10 and 12 million people, including some who are 3rd and 4th generation, but who declared themselves Indonesians.

The Bamboo network is a sort of Chinese Commonwealth built on business relationships between Chinese individuals and companies based in China and

\footnotetext{
${ }^{35}$ Political Map of the Republic of Indonesia, One World - Nations Online, http://www.nationsonline.org/oneworld/map/indonesia_map2.htm, accessed at 02.10.2016 ${ }^{36}$ Murray L. Weidenbaum, Samuel Hughes, The Bamboo Network: How Expatriate Chinese Entrepreneurs are Creating a New Economic Superpower in Asia, Simon and Schuster, 1996 ${ }^{37}$ Indonesia, CIA - The World Factbook, https://www.cia.gov/library/publications/the-worldfactbook/geos/print/country/countrypdf_id.pdf, accessed at 02.03.2016.
} 
residents and Chinese companies operating in South-East Asia, in Indonesia, Malaysia, Thailand, Vietnam, Philippines, Singapore and Taiwan. Gradually, the network has extended to other global areas of Chinese interest, such as sub-Saharan Africa, for example. This business network of high political influence is a soft power, a subversive vector, which is meant to ensure and to secure Chinese presence in the targeted areas.

2. Malaysia - and Indonesia share the control of Malacca Strait. In July 2016, China and Malaysia started negotiations for the construction of the third commercial port located in Carey Island, between Port Klang and the Malacca Strait $^{38}$. China is, already building a container terminal in Port Klang next to the Malacca Straits, the 12th largest commercial port globally, and is interested in the free zone around it, too. China is also participating in the Malaysia-China Kuantan Industrial Park development project in Gebeng City which will transform Kuantan port, currently the petrochemical hub of Malaysia, into a logistical hub ${ }^{39}$. Moreover, Kuala Lumpur officials stated Malaysia's desire to participate in the "silk belt" project with six ports, and to develop bilateral economic relations in many fields.

3. Philippines and Papua New Guinea - a region with numerous maritime straits $^{40}$. The naval, terestrial, and air interdiction imposed by China in the South China Sea led the Manila government to file a complaint against Beijing at the Permanent Court of Arbitration at The Hague ${ }^{41}$. Philippines won the trial under a resolution dated July 12, 2016. Although a signatory to the UN Convention on the Law of the Sea, Beijing does not recognize the jurisdiction of The Hague Court and, consequently, does not recognize and does not apply any of its resolutions. Consequently, the dispute has been moved into the law fare category of operations, with no foreseeable, in terms of time, clarification. But in recent months, we notice Philippines president', Rodrigo Duterte, political shift toward China (Duterte won the presidential elections in May 2016). This approach culminated with Duterte statement regarding the end, after 65 years, of the US-Philippines strategic

\footnotetext{
${ }^{38}$ Jiang Jie Bianji, idem. op.cit.

${ }^{39}$ Welcome To Kuantan Port Consortium, http://www.ijm.com/infrastructure/port/kuantanport/, accessed at 10.10.2016.

${ }^{40}$ Such as: the Strait of Bougainville - between the island of Bougainville in Papua New Guinea and the Choiseul island of Solomon Islands (British), Cebu Strait - between the Philippines Bohol and Cebu islands, Vitiaz Strait - between the Papua New Guinea and Long Island, Dampier Papua New Guinea Strait - between the Papua islands of New Britain and Umboi, Strait of Johore - between the Malay Peninsula in the area controlled by Malaysia and Singapore, the Strait of Balabac - between the islands of Palawan in the Philippines and Borneo in Indonesia, Pollilo Strait - between the islands Luzon and Pollilo in the Philippine, Surigao Strait - between the islands Leyte and Mindanao in the Philippines, Tablas Strait between the islands of Mindoro and Panay in the Philippines, Strait of Tanon - between the islands of Negros and Cebu in the Philippines, Strait of San Bernardino - between the islands Luzon and Samar in the Philippine, Strait San Juanico - between the islands of Samar and Leyte in Philippines and, especially, Luzon Strait - between Taiwan and Philippine island of Luzon.

${ }^{41}$ Territorial Disputes in the South China Sea, idem. op.cit.
} 
partnership and his administration political orientation towards China, statement that was „qualified” a few days later ${ }^{42}$. Obviously, in the context of Manila's political shift towards China there is a high probability for Beijing to get consent for a military base in the Philippine straits which would strengthen Chinese military influence of the flows in the Indo-Pacific area.

4. Australia - concession for 100 years starting in 2015, the Port of Darwin is located in the Northern part of the continent, near the Clarence Strait (between Melville Island and the mainland). The concession was won by a Chinese company, Landbridge, whose shareholders are connected to Beijing's military structures ${ }^{43}$. In September 2016, a consortium including the China Investment Corporation bought the share package of Australia's largest port of Melbourne ${ }^{44}$. The Port of Melbourne is located next to The Rip (aka The Heads Strait) connecting Port Phillip Bay (where the city of Melbourne is located) to the Bass Strait between the Australian mainland and the island of Tasmania.

5. The Chinese effort toward control of key strategic straits could also be interpreted to include Sri Lanka's, Malvinas' and Bangladesh' ports in the Chinese military plan. In the Indian Andaman Archipelago there are Homfray, Diligent and Duncan Straits and between India and Sri Lanka, the Palk Strait.

6. Also, some of the Sub Saharan ports targeted by the Chinese military plan are located at the mouth of some important straits such as the Mozambique Channel - between Mozambique and Madagascar, Pemba Strait - between the Tanzanian island of Pemba and the African continent, and the Zanzibar Strait - between the Tanzanian island of Zanzibar and Africa and the Cape of Good Hope.

\subsection{Persian Gulf and Suez Canal}

In late January 2016, Chinese President Xi Jinping visited, as part of a diplomatic tour, Saudi Arabia, Iran and Egypt, the main Middle East countries targeted by the Belt and Road Initiative ${ }^{45}$. Among these countries, Iran and Egypt control two of the major chokepoints, namely Hormuz Strait and the Suez Canal.

1. Persian Gulf

- Saudi Arabia - the bilateral discussions have addressed three major themes: the cooperation in the energy sector and the opening of Yasref refinery (built

\footnotetext{
${ }^{42}$ Neil Jerome Morales, Philippines' Duterte says didn't really mean 'separation' from U.S., Reuters, 22.10.2016, http://www.reuters.com/article/us-china-philippinesidUSKCN12L28T?utm_content $=$ bufferbd493\&utm_medium $=$ social \&utm_source=facebook . com\&utm_campaign=buffer, accessed at 20.10.2016.

${ }^{43}$ Callum Wood, China Buys Panama's Largest Port, the Trumpet, 22.06.2016, https://www.thetrumpet.com/article/13973.18.0.0/world/military/china-buys-panamaslargest-port, accessed at 10.10.2016.

${ }^{44}$ Cecile Lefort, Byron Kaye, Australian port sold for $\$ 7.3$ billion to consortium; China fund among backers,

Reuters, 19.09.2016, http://www.reuters.com/article/us-australia-privatisation-portsidUSKCN11P04O, accessed at 10.10.2016.

${ }^{45}$ President Xi Jinping visits Saudi Arabia, Egypt, Iran, Jan. 19-23, 2016, Xinhua, http://www.xinhuanet.com/english/cnleaders/201601xjp/, accessed at 10.10.2016.
} 
by Chinese state company Sinopec and the Saudi company Aramco), the issue of Uyghur Islamism in Western China and the cooperation within the Belt and Road Initiative. According to Council on Foreign Relations, 32.2 million barrels of oil representing over $50 \%$ of daily global sea-borne traffic $^{46}$ pass through the Indian Ocean. Most of these oil tankers are coming from the Persian Gulf, where Saudi Arabia is the de facto leader of the Sunni monarchies.

2. Strait of Hormuz

- Iran - is one of China's traditional partners in the region. During president Jinping's visit in Tehran he signed 17 memoranda on Iran's participation in China's Belt and Road Initiative ${ }^{47}$. But China's hegemonic ambitions must take into account Russian geopolitical interest in the region to which Iran is a critical pivot of the Russian inner security ring. Also Chinese strategists must consider Iran's Central Asia aims that are increasingly centered on the idea of restoring the ancient Persian Empire. These overlapping interests explain China's failure to take over the strategic Chabahar Port in the Straits of Hormuz that was instead leased to the Indians ${ }^{48}$.

3. Suez Canal

- Egypt - about $8 \%$ of the global cargo traffic pass via the Suez Canal. This canal shortens distances by $19 \%$ on the Singapore - New York route compared to the Panama Canal route, and by $42 \%$ on the Rotterdam Persian Gulf route versus the Cape of Good Hope route ${ }^{49}$. During the Chinese president's visit in Cairo a number of bilateral agreements aimed at strengthening Egypt's participation in Belt and Road Initiative were concluded. Some of the agreements are related to bilateral cooperation in the development and expansion of the Suez Canal, construction of Egypt's new administrative capital $^{50}$, and development of the China-Egypt Suez Economic and Trade Cooperation Zone, all based on a strategic partnership. Also, we should mention that Egypt's Sinai Peninsula affords a strategic position on the western shore of the Gulf of Aqaba. Near the entrance to the Gulf coming at the Red Sea Cairo owns both the Tiran and Sanafir strategic islands which were the subject of a commercial transaction with Saudi

\footnotetext{
${ }^{46}$ Eleanor Albert, Competition in the Indian Ocean, CFR Backgrounders, 30.10.2015, http://www.cfr.org/regional-security/competition-indian-ocean/p37201? cid=soc-facebookin-competition_indian_ocean-bgr-103115, accessed at 29.10.2015.

${ }^{47}$ Chinese president concludes three-nation Middle East tour, CCTV America, 24.01.2016, http://www.cctv-america.com/2016/01/24/chinese-president-concludes-three-nation-middleeast-tour, accessed at 10.10.2016.

${ }^{48}$ Asia Maritime Transparency Initiative, idem. op.cit.

${ }^{49}$ Ahmed Feteha, Egypt Shows Off \$8 Billion Suez Canal Expansion That the World May Not Need, Bloomberg, 04.08.2015, http://www.bloomberg.com/news/articles/2015-08-04/egyptshows-off-8-billion-suez-canal-gift-world-may-not-need, accessed at 10.10.2016. ${ }^{50}$ China, Egypt agree to boost cooperation under Belt and Road Initiative, Xinhuanet, 22.01.2016, http://news.xinhuanet.com/english/2016-01/22/c_135033384_2.htm, accessed at 10.10.2016.
} 
Arabia early in 2016. But the Saudi-Egyptian agreement was contested in an Egyptian court and the transaction failed ${ }^{51}$. However, due to her ongoing economic crisis a future international offer to sell these islands might be launched by Egypt where China might be among other potential buyers.

\subsection{Mediterranean Basin}

The main Mediterranean countries targeted by the Chinese strategy are either located around Gibraltar Straits as Morocco, Spain and, adjacent Algeria; those around the Otranto Straits including Albania, Croatia, and Montenegro, or the Levantine basin states - seen as a component of a strategic axis with the nearby Turkish Straits and the Suez Canal - thus, Israel, Greece, and Cyprus.

1. Straits of Gibraltar:

- Morocco - In May 2016, King Mohammed VI paid a state visit to China. On this occasion, 15 bilateral conventions were signed. Some of the conventions targeted port Tanger - Med and the adjacent free trade zone that lies in the immediate vicinity of the Gibraltar Straits ${ }^{52}$.

- Spain - a Chinese company, COSCO Ports, the world's second largest port terminal operator, could be one of the participants in the international tender for the construction of the third cargo terminal in the port of Algeciras. The Port of Algeciras is located on the Northern Mediterranean shore opposite to the port of Tangier ${ }^{53}$ also in the immediate vicinity of the Gibraltar Straits. According to auction organizers, after the deadline for tender submission on November 30, 2016, the identity of the bidders will become public.

- Algeria - the signing in January 2016, of a bilateral agreement on construction and operation by Chinese companies of the new commercial Port of Cherchell located $60 \mathrm{~km}$ west from the capital, Algiers ${ }^{54}$.

2. Levantine Basin:

- Israel - in March, 2015, the Chinese company Shanghai International Port Group won the international tender for the development and management for 25 years of the new Port of Haifa in Northern Israel ${ }^{55}$.

\footnotetext{
${ }^{51}$ Ruth Michaelson, Egyptian court quashes deal to transfer Red Sea islands to Saudi Arabia, The Guardian, 21.06.2016, https://www.theguardian.com/world/2016/jun/21/egyptian-courtquashes-transfer-red-sea-islands-saudi-arabia, accessed at 10.10.2016.

${ }^{52}$ Nadia Lamlili, Maroc-Chine: une quinzaine de contrats signés durant la visite de Mohammed VI, Jeunne Afrique, 17.05.2016,

http://www.jeuneafrique.com/325644/politique/pluie-de-contrats-entre-maroc-chine/, accessed at 10.10.2016.

${ }^{53}$ Angela $Y u$, COSCOCS unit to bid for container terminal at Algeciras port, Fairplay, 25.08.2016, http://fairplay.ihs.com/ports/article/4274001/coscocs-unit-to-bid-for-containerterminal-at-algeciras-port, accessed at 10.10.2016.

${ }^{54}$ China, Algeria to build mega sea port, Xinhua, 18.01.2016, http://news.xinhuanet.com/english/2016-01/18/c_135018002.htm, accessed at 10.10.2016

${ }^{55}$ Kenneth Rapoza, Albania Becomes Latest China Magnet, Forbes, 13.06.2016, http://www.forbes.com/sites/kenrapoza/2016/06/13/albania-becomes-latest-chinamagnet/\#2fe4850e11b0, accessed at 10.10.2016.
} 
- Greece - in April 2016, Chinese company COSCO Piraeus bought a 67\% interest in the Port of Piraeus located on the Saronic Gulf just a few kilometers south of Athens. Pireaus is Greece's largest port and world's third largest in numbers of passengers.

- Cyprus - in January 2016, Chinese COSCO tried, but failed to win control of the management of Limassol port through an international tender ${ }^{56}$.

3. Otranto Strait - between Apulia (Italy) and Albania these straits separate the Adriatic Sea from the Ionian Sea.

- Albania -Chinese companies have expressed interest in investing in the ports of Durres and Shengjin ${ }^{57}$.

- Croatia - Chinese companies have expressed interest in investing in the port of Rijeka ${ }^{58}$.

- Montenegro - Chinese companies have expressed interest in the port of $\mathrm{Bar}^{59}$.

\subsection{Turkish Straits and the Black Sea}

The main countries targeted by the Chinese strategy are Turkey and the Black Sea countries Romania, Bulgaria and Georgia.

- Turkey - during September 2015, COSCO Pacific and China Merchants Holdings International bought a $65 \%$ interest in the Kumport terminal in the Ambarli port complex, the largest on Turkish territory. Ambarli port is located in the northwestern portion of the Sea of Marmara on the European side of Istanbul near the strategic Bosphorus Straits that separate the Black Sea from the Sea of Marmara. The Bosphorus is the narrowest strait in the world used for international navigation. Kumport terminal, the third largest in Turkey, manages $13 \%$ of the country's container traffic ${ }^{60}$. In addition, Turkey is one of the key states in the Mediterranean corridor of China's Belt and Road Initiative.

- Romania - Chinese companies expressed interest in investing in the Port of Constanta.

\footnotetext{
${ }^{56}$ Maria Petrakis, COSCO charts course for entry into Cyprus, China Daily, 29.01.2016, http://europe.chinadaily.com.cn/business/2016-01/29/content_23301596.htm, accessed at 10.10.2016

${ }^{57}$ Kenneth Rapoza, idem. op.cit.

${ }^{58}$ Vedran Pavlic, Chinese Investors the Only Remaining Hope for Port of Rijeka, total croatia news, 29.02.2016, http://www.total-croatia-news.com/business/2658-chinese-investors-theonly-remaining-hope-for-port-of-rijeka, accessed at 10.10.2016.

${ }^{59}$ Chinese top officials voice interest in developing Montenegro's Port of Bar, PM Đukanović notes following China-CEE summit in Suzhou, Prime Minister of Montenegro, 26.11.2015, http://www.predsjednik.gov.me/en/news/154809/PM-dukanovic-meets-with-China-s-topofficials-Expressed-interest-in-cooperation-in-developing-Port-of-Bar.html, accessed at 10.10.2016.

${ }^{60}$ Vincent Wee, Cosco Pacific in jv to buy into Turkey's Kumport Terminal, Seatrade Maritime News, 17.09.2015, http://www.seatrade-maritime.com/news/asia/cosco-pacific-injv-to-buy-into-turkeys-kumport-terminal.html, accessed at 10.10.2016.
} 
- Bulgaria - Chinese companies expressed interest in investing in the Ports of Varna and Burgas ${ }^{61}$

- Georgia - US-Georgian consortium won the tender on the construction of the Anaklia deep sea port located $25 \mathrm{~km}$ from the port of Poti, although, initially, a Chinese company was preferred. Anaklia port is scheduled to be part of the Chinese Belt and Road Initiative and Georgia is one of the founding members of the Asian Infrastructure Investment Bank, one of the financial instruments provided in support of the Chinese strategy in AfroEurasia $^{62}$.

It is important to note that China's failure in the Black Sea region must be linked to geopolitical interests in the area where Russia and EU/NATO play out their competing spheres of influence.

\subsection{Nordic Routes}

Following the accelerated thawing of the Arctic ice cap northern sea routes will take away much of the traffic through the Suez Canal and Malacca Straits. In these circumstances, the Bering Strait, located between Alaska and Siberia, separating the Pacific Ocean from the Arctic Ocean, will become a future chokepoint of utmost importance as future Barentz, Iceland, Greenland ports, as well as ones located along the Arctic coastline, become operational.

But a major power in the region is the Russian Federation with which Beijing leaders are cooperating politically and economically within the BRICS and the Shanghai Cooperation Organization. The relationship between the two emerging powers is marked by geopolitical competition in Central Asia, the Caucasuses, the Levant, the African states previously affiliated to the Soviet Union's sphere of influence and potentially, in the Arctic areas, belonging to Russian Federation's internal security ring covered by the "silk bridge".

In this context, the "cold peace" in bilateral relations is likely to turn into confrontation if there is no mutual understanding regarding divisions of spheres of influence between the two powers (ie: the northern hemisphere for the Russian Federation and the Southern hemisphere to China) or if this understanding is violated. In this respect a nuance introduced by Sergei Alexandrovich Karaganov ${ }^{63}$,

\footnotetext{
${ }^{61}$ Ion TIŢA-C $\breve{L I N}$, Portul Constanţa e mai puţin atractiv pentru China decât porturile bulgăreşti şi turceşti, Cuget Liber, 27.02.2016, http://www.cugetliber.ro/stiri-economieportul-constanta-e-mai-putin-atractiv-pentru-china-decat-porturile-bulgaresti-si-turcesti282102, accessed at 10.10.2016

${ }^{62}$ Wade Shepard, Anaklia 'Silk Road' Port Set To Transform Georgia And Enhance ChinaEurope Trade, Forbes, 29.09.2016, http://www.forbes.com/sites/wadeshepard/2016/09/29/silk-road-anaklia-deep-sea-port-setto-transform-georgia/\#6cb70f903f47, accessed at 10.10.2016.

${ }^{63}$ Sergei Karaganov is the Dean of the School of International Economics and Foreign Policy in Moscow and the current foreign policy adviser to President Vladimir Vladimirovich Putin.
} 
the author of Eurasian Union from Lisbon to Vladivostok project ${ }^{64}$ which supports Russia pivoting to the East by integrating Eurasian Economic Union with the Silk Belt and Road, China is seen as a leader, not the hegemon ${ }^{65}$.

Outside the Russian Federation, the main targets of the Chinese strategy in the region have been Iceland, Greenland, Norway and Finland.

- Bering Straits - China supported the project of "China-Russia-CanadaAmerica" Railway Line that would include a $200 \mathrm{~km}$ underwater tunnel beneath the Straits ${ }^{66}$.

- Norway and Finland - Chinese companies declared themselves interested in investing in the Norwegian port of Kirkenes' various development projects, and in the construction of a railway that would unite the Norwegian town of Kirkenes with the Finnish town, Rovaniemi ${ }^{67}$.

- Iceland - China declared itself ready to develop, in partnership with Iceland, a transit port in one of the following locations: Eyjafjörður, Hvalfjörður or Reyðarfjörður. The project remains in debate as a result of EU opposition. But cooperation between China and Iceland exceeds harbor plans reaching into different areas of ecology and green energy production, hydrocarbon extraction, fishing, food industry etc ${ }^{68}$.

- Greenland - In 2015, Chinese company General Nice took over the Isua iron ore exploitation project marking China's entry among mine owners in the Arctic. It is expected that this investment will be followed, among other possible investments, by the construction of port facilities designed to serve the future mine ${ }^{69}$.

- Netherlands - In May 2016, the Chinese company COSCO Ports bought $35 \%$ of Euromax terminal in the port of Rotterdam stakes from the Hong

\footnotetext{
${ }^{64}$ Sergei Karaganov, Eurasian Way Out of the European Crisis, 07.06.2015, RUSSIA IN GLOBAL AFFAIRS, http://eng.globalaffairs.ru/pubcol/Eurasian-Way-Out-of-the-European-Crisis-17505, accessed at 07.07.2016.

${ }^{65}$ Marijke Vermeulen, Dusting off the Karaganov doctrine, 17.04.2014, http://www.europeangeostrategy.org/2014/04/dusting-karaganov-doctrine/, accessed at 07.07.2016.

${ }^{66}$ Ishaan Tharoor, China may build an undersea train to America, Washington Post, 09.05.2014, https://www.washingtonpost.com/news/worldviews/wp/2014/05/09/china-maybuild-an-undersea-train-to-americal, accessed at 10.10.2016.

${ }^{67}$ Chinese Companies to Invest in Norwegian Ports Near Russian Border, Sputnik International, 13.06.2015, https://sputniknews.com/business/201506131023317672/, accessed at 10.10.2016.

${ }^{68}$ Arthur Guschin, China, Iceland and the Arctic, THE DIPLOMAT, 20.05.2015, http://thediplomat.com/2015/05/china-iceland-and-the-arctic/, accessed at 10.10.2016 ${ }^{69}$ Lucy Hornby, Richard Milne, James Wilson, London Chinese group General Nice takes over Greenland mine, FINANCIAL TIMES, https://www.ft.com/content/22842e82-9979-11e4-a3d7-00144feabdc0, accessed at 01.10.2016.
} 
Kong registered company, Hutchison Port Holdings ${ }^{70}$. The Dutch port of Rotterdam, the third largest in terms of global goods traffic after Singapore and Shanghai, is one of the European strategic ports included, among others, in a future liquefied natural gas distribution network.

- Germany - In October 2016, China expresses interest in buying Aixtron semiconductor company and in investing in Port of Hamburg as well ${ }^{71}$.

\subsection{Western Hemisphere - the Panama Canal, the Strait of Magellan}

Chinese strategy in the Western Hemisphere targets both Americas, the two major chokepoints of Panama Canal and the Strait of Magellan, as well as the Caribbean transport routes.

\section{South America}

- Venezuela - in 2011, China Harbor Engineering Company and the Venezuelan state company Bolivarian Ports signed an agreement for the construction of a container terminal in Venezuela's main port, Puerto Cabello $^{72}$.

- Ecuador - in 2009, a Chinese company won the international tender for the construction and concession for 30 years of the management of deep-sea port of $\mathrm{Manta}^{73}$.

- Brazil - is China's BRICS partner. In 2010, China started the construction of São João da Barra super-port for heavy ships, located near the Brazilian capital, Rio de Janeiro ${ }^{74}$. The port is functional today.

- Argentina and Chile, geographically linked to Cape Horn, Straits of Magellan and Straits of Drake (between Cape Horn, Antarctica and Chile) as well as to other smaller straits ${ }^{75}$.

\footnotetext{
${ }^{70}$ Angela Yu, idem.op.cit.

${ }^{71}$ Emily Tamkin, Germany Inc. Is Not for Sale to China, Berlin Says, Foreign Policy, 31.10.2016, http://foreignpolicy.com/2016/10/31/germany-inc-is-not-for-sale-to-chinaberlin-

says/?utm_content $=$ bufferb $9266 \& u t m \_m e d i u m=$ social $\& u t m \_s o u r c e=f a c e b o o k . c o m \& u t m \_c a$ mpaign=buffer, accessed at 01.11.2016.

${ }^{72}$ Wang Guanqun, Venezuela, China agree to build $\$ 520$ mlm terminal in northern Venezuelean port, XinHuanet, 10.05.2011, http://news.xinhuanet.com/english2010/china/2011-10/05/c_131175190.htm, accessed at 10.10.2016.

${ }^{73}$ Clifford Krauss, Keith Bradsheer, China's Global Ambitions, Cash and Strings Attached, New York Times, 24.07.2015, http://www.nytimes.com/2015/07/26/business/international/chinas-global-ambitions-withloans-and-strings-attached.html?_r=0, accessed at 10.10.2016.

${ }^{74}$ Tom Phillips, Brazil's huge new port highlights China's drive into South America, The Guardian, 15.09.2016, https://www.theguardian.com/world/2010/sep/15/brazil-port-chinadrive, accessed at 01.10.2016.

${ }^{75}$ Such as the Strait of Le Maire between Tierra del Fuego and the Argentinian island of Los Estados, Falkland Strait between the Eastern and Western Falkland islands (British territory
} 
Argentina - On 16 November 2015, during the G20 meeting in Turkey, Argentina and China signed an agreement for the construction of two nuclear reactors worth of $\$ 15$ billion, and for two dams in Santa $\mathrm{Cruz}^{76}$ that would have been $85 \%$ funded by Beijing. In return for this investment, China was to receive a site for a future satellite radar station in Neuquen and agreement to transform the Santa Cruz fishing port of Caleta Oliva near the Strait of Magellan into an industrial port. The current Argentinian administration of President Mauricio Macri elected in 2015 initially slowed down these projects, but the bilateral relations seem to have been revived in recent months, according to Argentine Ambassador to Beijing, Guelar Diego. Moreover, the Argentinean official stated that the volume of Chinese investment in his country has reached $\$ 25$ billion by including infrastructure projects, and is going to be extended in agriculture, tourism, mining, telecommunications etc ${ }^{77}$.

Chile - The bilateral relationship, spurred by the free trade agreement signed in 2005, included the Valparaiso port facilities that are also en route to the Straits of Magellan. The Port of Valparaiso, the largest in the southern hemisphere, twinned with the Port of Shanghai and is in the full process of expansion and modernization. According to Gonzalo Davagnino, the Port of Valparaiso's general manager, China was invited to participate in these investment projects due to the fact that in 2014, $30 \%$ of the total volume of Chilean imports through the Port of Valparaiso came from China $^{78}$.

\section{North America}

Nicaragua - in 2013, Nicaragua's National Assembly approved a concession for 50 years for management of the future Nicaragua Grand Canal (aka Grand Inter-oceanic Canal) to the main financier, Hong Kong Nicaragua Canal Development Investment Company (HKND Group), led by Chinese billionaire Wang Jing ${ }^{79}$. The future Nicaragua Grand Canal would connect the Caribbean Sea and the Atlantic Ocean to the Pacific Ocean. Obviously, if built, the future canal would be an alternative to the already operational Panama Canal considered too narrow for Panamax cargo

overseas claimed by Argentina) and Murray Channel of Tierra del Fuego Archipelago, between the islands Chilean islands of Hoste and Navarino .

${ }^{76}$ Argentina and China reaffirm strategic relation and agree to review contracts, Merco Press, 02.04.2016, http://en.mercopress.com/2016/04/02/argentina-and-china-reaffirmstrategic-relation-and-agree-to-review-contracts, accessed at 01.10.2016.

${ }^{77}$ China's leading role in Argentina reviewed and confirmed by Macri, MercoPress, 02.08.2016, http://en.mercopress.com/2016/08/02/china-s-leading-role-in-argentinareviewed-and-confirmed-by-macri, accessed at 01.10.2016.

${ }^{78}$ Port of Valparaiso brings Chile and China closer together, South China Morning Post, 30.09.2015, http://www.scmp.com/presented/business/topics/2015-chile-businessreport/article/1862715/port-valparaiso-brings-chile, accessed at 01.10.2016.

${ }^{79}$ Christopher Dickey, Will Nicaragua Ever Get Its Grand Canal?, The Daily Beast, 14.05.2016, http://www.thedailybeast.com/articles/2016/05/14/will-nicaragua-ever-get-itsgrand-canal.html, accessed at 01.10.2016. 
vessels ${ }^{80}$ desite recent modernization and enlargement. For now, the construction progress is moving sluggishly due to financial problems, but the contract between the Nicaraguan government and the Chinese company remains in force. Also, the two sides pledged to build a future port on the Pacific Ocean whose profile (military and/or civilian) was not specified.

- Panama - The sluggishness of HKND's investment, which is most likely backed by the Chinese state, must be connected to the purchase by the Chinese company, Landbridge Group, of the nearby Margarita Island Port. This port, the largest within the Panama Canal Zone, is located at the Atlantic extremity, in the Colón Free Zone ${ }^{81}$. It is important to note that the new Chinese acquisition gives control over a maritime hub which impacts both the east-west axis between the Far East and Western Europe, and the north-south axis, between the Americas where pass annually over 12,000 commercial ships. But there are other Chinese investments in the Panama Canal, too. On March 1, 1997, the Chinese company Hutchinson Whampoa Limited, which is possibly connected to the State Council of Popular Republic of China ${ }^{82}$, leased, for 50 years the management of two other ports, respectively Balboa and Cristobal, located at the Atlantic and Pacific extremities of the $\mathrm{Canal}^{83}$.

- Cuba - The Chinese company China Communications Construction Company Ltd has managed since the beginning of 2016 a project to modernize and expand the Santiago de Cuba Port, the second largest in Cuba after the Port of Mariel. China is also the financier6 of Santiago de Cuba's port located $45 \mathrm{~km}$ west of state capital, Havana.

- Bahamas - in 2000, in Port Freeport, located 60 nautical miles from the US state of Florida, the Chinese company Hutchison Whampoa Limited built one of the largest container terminals in the world ${ }^{84}$.

- Mexico - since 2007, the same Chinese company Hutchison Whampoa, has represented a major investor in ports on both the Atlantic Coast in the province of Veracruz, and the Pacific Coast in the provinces of Manzanillo, Michoacán and two ports in Ensenada. Also, Hutchison Whampoa officials have declared interest in the construction of a super-port in Punta Colonet ${ }^{85}$

\footnotetext{
${ }^{80}$ Steven Mufson, An expanded Panama Canal opens for giant ships, Washington Post, 26.06.2016, https://www.washingtonpost.com/world/the_americas/an-expanded-panamacanal-opens-for-giant-ships/2016/06/26/11a93574-37d1-11e6-af02-1df55f0c77ff_story.html, accessed at 10.10.2016.

${ }^{81}$ Callum Wood, idem. op.cit.

${ }^{82}$ Christopher Ruddy, Stephan Archer, Chinese Company Completes World's Largest Port In Bahamas, 20.01.2000, http://www.rense.com/politics6/chinabahamas_p.htm, accessed at 10.10.2016.

${ }^{83}$ Ibidem.

${ }^{84}$ Christopher Ruddy, Stephan Archer, idem. op. cit.

${ }^{85}$ The Danger in China's Mexican Port Grab, The Trumpet, 18.01.2007, https://www.thetrumpet.com/article/3266.2.0.0/world/globalization/the-danger-in-chinasmexican-port-grab, accessed at 10.10.2016.
} 
Bay and in the modernization and expansion of the Lazaro Cardenas deep sea port on the Pacific coast.

China expresses interest in investing in many other ports and economies such as Guatemala, Honduras, Belize, San Salvador etc, so the list goes on.

\subsection{What are the geostrategic implications of China's approach?}

At the beginning of the eighteenth century British politician and seafarer Sir Walter Raleigh (1552 (4) -1618) stated in one of the speeches that "for whosoever commands the sea commands the trade; whosoever commands the trade of the world commands the riches of the world, and consequently the world itself ${ }^{86 "}$. Several centuries later, US Admiral Alfred Thayer Mahan (1840-1914), author of Sea Power theory, reiterated Raleigh's imperative saying that who controls maritime chokepoints controls shipping insisting on the need to develop naval power as the sole guarantor of maritime channel security. Contemporaneous to Mahan, British geo-strategist Sir Halford John Mackinder (1861-1947), author of the theory of global domination, drew attention to China as a future recipient of Eurasia's riches coupled with the strategic advantage of unhindered Pacific Ocean access. These two advantages, wealth and free maritime access, in Mackinder's opinion, will provide China with great source of power able to transform her in the „ruler of the world”. Another American geo-strategist, Nicholas John Spykman (1893-1943), author of the Rimland Theory, and who was also known as the spiritual father of the containment policy, reformulated Raleigh's imperative saying that whoever controls the shores, dominates Eurasia and whoever dominates Eurasia, rules the world ${ }^{87}$. In this regard, Spykman said that human civilization is a civilization of water developed along coastlines or rivers where access to the oceans is one of the motivations that ignited the territorial expansion of continental states (such as Russia for example).

Accepting the above theories makes it obviously that Beijing's global maritime strategy literally applies the principles of maritime domination described by Raleigh, Mahan, Mackinder and Spykman, in order to transform China into a global hegemon, as the following map, Fig 4, suggests.

The map illustrates China's maritime chokepoints targets and her level of control along global shores. We observe the concentration both in the southern and northern hemispheres with the subsequent strategic consequences as described by the Rimland Theory and the comments of Raleigh, Thayer and Mahan. Fig.2 map illustrates the Chinese Military Plan in Afro-Eurasia. We notice the presence of the

\footnotetext{
${ }^{86}$ Sir Walter Raleigh, A Discourse of the Invention of Ships, Anchors, Compass, \&c., The Works of Sir Walter Ralegh, Kt., vol. 8, p. 325 (1829, reprinted 1965) apud http://www.bartleby.com/73/2044.html, accessed at 01.08.2015, (traducere proprie din limba engleză).

${ }^{87}$ Nicholas J. Spykman, The Geography of the Peace, New York: Harcourt, Brace and Company, 1944, p. 43.
} 
planed military bases right next to three of the seven global maritime chokepoints: the Straits of Malacca, Hormuz and Bab el-Mandeb. Chinese military plans also provide for bases located in the Gulf of Aden, Cape of Good Hope, Mozambique Channel, in the numerous maritime straits in the South China Sea, Andaman, Seychelles, Malvinas Archipelagos, and extending to West Africa in the Gulf of Benin. As we notice in Fig.4, there is a significant Chinese economic presence adjacent to other two global chokepoints: the Panama Canal and the Turkish Straits, as well as to important strategic straits such as Gibraltar, Magellan, Cape Horn, the Mozambique Channel, and the many straits of Indonesian, Philippine, Andaman, Malvinas, Greek, and Caribbean Archipelagos. Also noted is the economic encirclement of the Danish straits, vital to Russian oil traffic, and the only chokepoint not under Chinese military and/or economic control.

The Danish Straits absence from China's immediate strategic objectives list, as well as the failure of taking over Iranian Chabahar Port management or the failure of economic taking over attempts of the Black Sea ports, should be regarded as the result of a non-confrontational policy against Russia in which Beijing does not want to test relations, for the moment.

Figure 4. China's taking control of maritime straits and global shoreline process phases

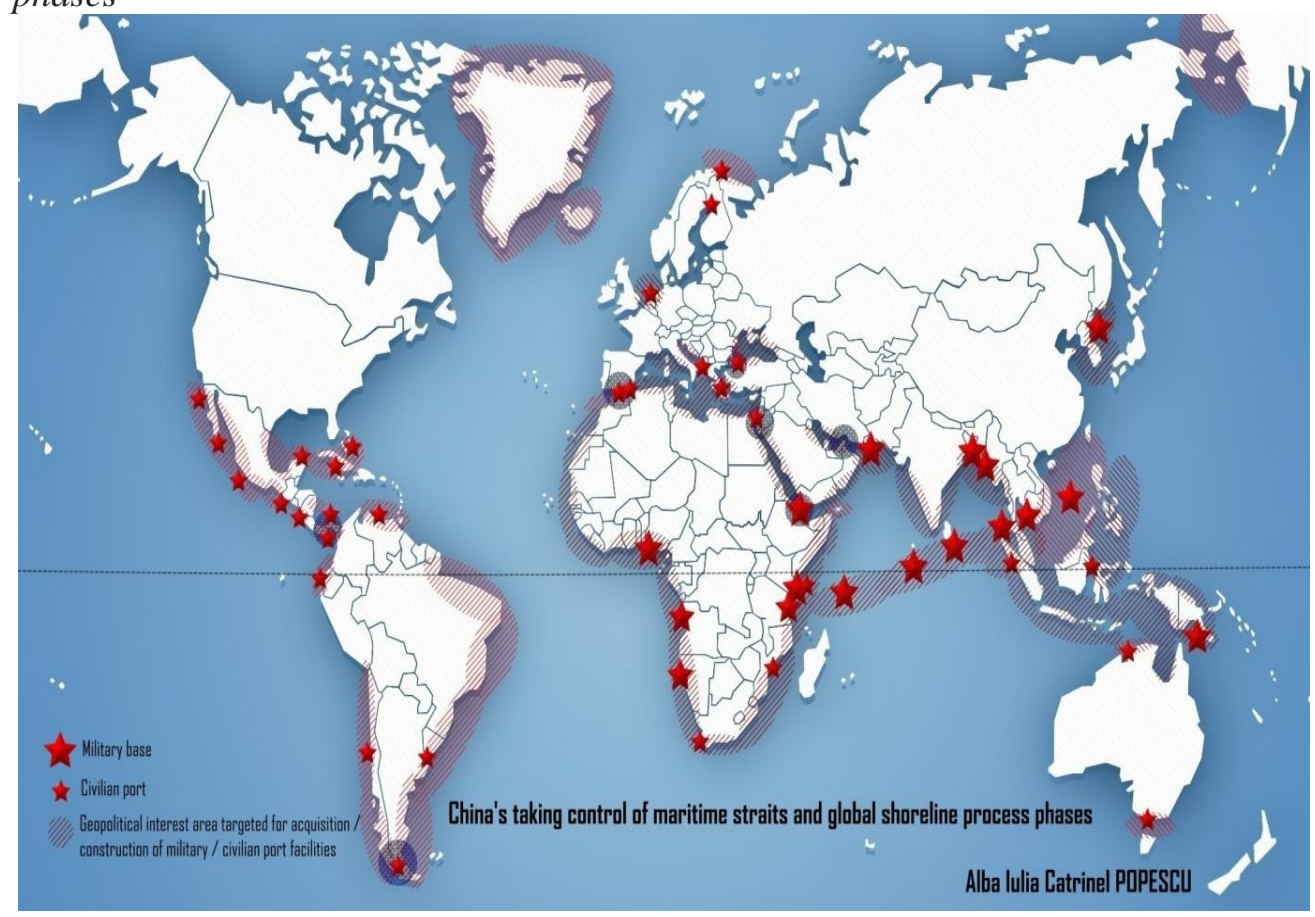


It is useful to remember that the need to secure investments and transport routes was the argument used by Beijing officials to explain their extensive military presence in Sub Saharan and South Asian countries. Obviously, in the future, China could use the same argument to overlay her current economic presence with military forces in the many other straits and ports where she has now or is developing and economic interest.

If we analyze the situation in the Caribbean we see a concentration of Chinese investment in port facilities in the Bahamas and Cuba, which must be combined with those in Mexico, Ecuador, Nicaragua and Panama Canal. Given that the US has lifted the restriction on the export of hydrocarbons, it is obvious that American energy tankers will transit this region. Furthermore, the current Chinese economic growth in the Gulf of Mexico should be considered against the massive US investment in the same region from oil drilling stations to liquefied gas terminals and port facilities. This is underscored by statistics regarding oil traffic chokepoints and the level of Chinese involvement in the management of those state's main oil ports. But not only hydrocarbons are transported by sea corridors, many other goods from weapons to strategic mineral commodities are also transited through these ports. Therefore, it becomes obvious that we are witnessing China's global takeover of oil and commodity maritime traffic control, an aspect that will generate an unquestionable economic and strategic superiority.

Also, massive investments made by Chinese companies, mostly in emerging countries from Africa, Asia, Central and South America, have become an important political and diplomatic instrument for China. This instrument can put pressure on governments through its impact on national security whenever bilateral dysfunction may occur (i.e. impact on national economy by increasing of the unemployment, impact on the GDP volume, on the monetary policy stability). Similarly, if China should choose to disrupt traffic through any of the aforementioned straits a global economic crisis could quickly result. These elements should not be overlooked given that China has already conducted a recent economic war, her two-month long withholding of rare earths exports to $\mathrm{Japan}^{88}$ in 2010, or by blocking, in the same year 2010 , the rare earth exports to the US, ${ }^{89}$ despite available bilateral commercial contracts.

Also, Chinese economic and military presence in the major ports and global maritime straits allows an important amount of military and civilian, maritime and

\footnotetext{
${ }^{88}$ Keith Bradsher, Amid Tension, China Blocks Vital Exports to Japan, The New York Times, 22.09.2010, http://www.nytimes.com/2010/09/23/business/global/23rare.html pagewanted $=$ all \&_r=0, accessed at 10.10.2016.

${ }^{89}$ Gus Lubin, China just banned exports of Rare Earth Minerals to the US, Business Insider, 19.10.2010, http://www.businessinsider.com/chinas-has-just-started-ban-of-rare-earthmetal-exports-to-the-us-2010-10, accessed at 10.10.2016.
} 
terrestrial data collection and analysis opportunities that are and it will be beneficial to China's geopolitical interests. This aspect should take into consideration that the collection of intelligence from humans, the so-called HUMINT, remains the most valuable source of information and the only alternative when, for whatever reason, technological sources fail or are compromised.

And, last but not least, Chinese military interdiction in the South China Sea and the translation of the local dispute into a "law fare" action, where international legal resolutions are not respected, could threaten commerce and security. Consequently, if China were successful in a military takeover of global maritime chokepoints the impact on economic, political and global security will be significant.

It is important to note that the Chinese strategy is one of smart-power following a sequence of steps:

- first step is always an application of soft-power starting with an economic takeover through the purchase of shares/concession in a enterprise in exchange for investment in modernization/expansion of the host country's industrial assets, as well as investments in infrastructure and other economic sectors;

- $\quad$ second step is the strengthening political relations through a policy without ethical constraints (i.e. the relationship between China and Omar al Bashir's Sudanese administration. Omar al Bashir has been convicted by the International Criminal Court for war crimes in Darfur ${ }^{90}$ );

- third step advantageous cultural exchanges and education programs for young people in Chinese universities that ensures a recruitment pool for future agents of influence,

- final step is the application or threat of hard-power consisting of strengthening the bilateral military cooperation and building the Chinese military bases.

The aforementioned strategy may be, for example, perfectly identified in SubSaharan Africa where China has already advanced to the final phase, the development of naval bases.

Vectors used to implement the strategy, besides the diplomatic apparatus, are evidenced by Chinese businessmen residing in the targeted territory as well as Chinese companies and consortia who built up the "bamboo network", or a sort of Chinese Commonwealth which can already be observed operating in the South China Sea and in Sub-Saharan Africa. From the point of view of shareholders, the companies involved in this process are public, private and mixed. But, some private companies may have extensive connections with state military and political structures in Beijing, and can be considered outposts of the Chinese state in the targeted regions. It is important to note that in Sub-Saharan Africa, for example,

${ }^{90} \mathrm{Al}$ Bashir Case, https://www.icc-cpi.int/darfur/albashir, accessed at 10.10.2016. 
Chinese investments were made mostly by ethnic Chinese staff. But, instead of going back to China upon project completion, the Chinese staff often permanently establish in the regions creating exclusive colonies, and, in some cases sparking discontent among locals ${ }^{91}$.

These data should be corroborated with China's decision to build, by the end of 2020, a military fleet consisting of 351 ships $^{92}$. We have to mention that, at present, the Chinese military fleet is second in tonnage globally after the US but first one in number of combatants.

Also, these data should also be corroborated with some assets that support China's global superpower transformation approach. China is:

- the biggest demographic power with an expanding population of over 1.5 billion people;

- the world's second economic power after the US and could overtake the US in 2020, according to a International Monetary Fund ${ }^{93}$ forecast;

- a permanent member of the United Nations Security Council, the BRICS organization, the Shanghai Cooperation Organization, and the Group of 20 most developed countries G20;

- a Confucian society that is hierarchical and disciplined, that actively supports the nationalist feelings by Beijing's official ideology, thus without an internaal component of religious strife that has inflamed recent sectarian clashes and wars in other countries;

- rich in important strategic resources ores, especially rare earth metals, which will ensure a future abundant supply of raw material for future technologies;

- has a generally positive political and economic relationship with the Islamic world (excepting the Uyghar problem);

- maintains a "cold peace" relationship with Russia despite geopolitical competition. For now, their bilateral cooperation is based on tenuous economic and political cooperation that is used by both Moscow and Beijing as a bargaining vector in the relationship with the West.

Certainly, there are aspects that weaken China:

- more than 800 million citizens living in absolute poverty in rural regions of the country;

\footnotetext{
${ }^{91}$ Sofie Geerts, Namhla Xinwa, Deon Rossouw, Africans' Perceptions of Chinese Business in Africa. Survey, Ethics Institute of South Africa, Globethics.net Focus No. 18, http://www.globethics.net/documents/4289936/13403252/GE_Focus_18_web_1.pdf, p.11, accessed at 10.10.2016.

${ }^{92}$ Kris Osborn, Report: Chinese Navy's Fleet Will Outnumber U.S. by 2020, Military.com, 03.12.2014, http://defensetech.org/2014/12/03/report-chinese-navys-fleet-will-outnumber-us-by-2020/, accessed at 22.10.2015

${ }^{93}$ List of Countries by Projected GDP, Statistic Times, 21.10.2016, http://statisticstimes.com/economy/countries-by-projected-gdp.php, accessed at 23.10.2016.
} 
- an export-led economy and dependence on investments from and in other countries, as well as, export markets which might be a vulnerability within the context of China's seemingly overly-extended investments in farflung places;

- lack of domestic energy supplies, thus dependence on foreign suppliers;

- technological gap with the West, especially in aerospace and military technologies;

- lack of cultural attractiveness, a significant aspect of soft power;

- potential outbreaks of unrest and instability in Tibet and the Uyghur region;

- major economic and social disparity between China's mainland, Rimland and islands that can lead to new outbreaks of internal instability;

- historical issues with Taiwan, Japan, South Korea and in the South China Sea riparian states as well as geopolitical competition with India, the US and Russian Federation that generates geopolitical balancing mechanisms and barriers to the broadening the Chinese influence.

But, in substance, China's potential to transform herself into a superpower remains high.

Examining at all these data we can conclude that globalization's greatest beneficiary has been China because she has capitalized on this neoliberal economic opening with the strategic, political and financial, instruments of a unified state. In this situation, in the absence of a counter strategy, it is higly probable that China's taking over of commercial and/or military control of global shores and straits will continue. Obviously, the result of this maritime „China-lization” the will be the emergence of China as the new naval and maritime superpower.

\section{References:}

Albert, E. 2015. Competition in the Indian Ocean, CFR Backgrounders, http://www.cfr.org/regional-security/competition-indian-ocean/p37201?cid=socfacebook-in-competition_indian_ocean-bgr-103115;

Asia Maritime Transparency Initiative, CSIS, http://amti.csis.org/indian-ocean/;

Bender, J. 2015. These 8 narrow chokepoints are critical to the world's oil trade, Business Insider, http://www.businessinsider.com/worlds-eight-oil-chokepoints-2015-4;

Chinese President Xi highlights that common understanding and joint efforts have brought Sino-Maldives relations to the cusp of elevation to a higher plane. President Yameen thanks President Xi for positively considering his proposal to support the construction of the Male'-Hulhule' Bridge, The President's Office, 15.09.2014, http://www. presidencymaldives.gov.mv/Index.aspx?lid=11\&dcid=14821;

Chinese paper advises PLA Navy to build overseas military bases, 08.01.2013, http://www.china-defense-mashup.com/chinese-paper-advises-pla-navy-to-buildoverseas-military-bases.html;

Hartman, A. 2014. Chinese naval base for Walvis Bay, The Namibian, http://www.namibian.com.na/ index.php?id=130693\&page=archive-read;

ICC International Maritime Bureau Piracy and Armed Robbery Against Ships -2014 Annual 
Report, Report for the Period 1 January - 31 December 2014, ICC International Maritime Bureau, January 2015, http://www.hellenicshippingnews.com/wpcontent/uploads/2015/01/2014-Annual-IMB-Piracy-Report-

ABRIDGED.pdf\#page $=5 \&$ zoom $=$ auto, $-107,513$;

Joint security update on Operation Indian Ocean by Somali Government and AMISOM, http://amisom-au.org/2014/10/joint-security-update-on-operation-indian-ocean-by-somaligovernment-and-amisom/;

Karaganov, S. 2015. Eurasian Way Out of the European Crisis. Russia in Global Affairs, http://eng.globalaffairs.ru/pubcol/Eurasian-Way-Out-of-the-European-Crisis-17505;

Mapping China's Maritime Ambition, Stratfor. 2014. https://www.stratfor.com/analysis/mapping-chinas-maritime-ambition;

President Xi Jinping visits Saudi Arabia, Egypt, Iran. 2016. Xinhua, http://www.xinhuanet.com/english/cnleaders/201601xjp/;

Sir Raleigh, W. 1965. A Discourse of the Invention of Ships, Anchors, Compass, \&c., The Works of Sir Walter Ralegh, Kt., vol. 8, p. 325 (1829, reprinted 1965) apud http://www.bartleby.com/73/2044.html;

Spykman, N.J. 1944. The Geography of the Peace, New York: Harcourt, Brace and Company, 1944;

Territorial Disputes in the South China Sea, Council on Foreign Relations. 2015. http://www.cfr.org/global/global-conflict-tracker/p32137\#!/conflict/territorialdisputes-in-the-south-china-sea;

Vermeulen, M. 2014. Dusting off the Karaganov doctrine. http://www.europeangeostrategy.org/2014/04/dusting-karaganov-doctrine/;

Vision and Actions on Jointly Building Silk Road Economic Belt and 21st-Century Maritime Silk Road. 2015. Issued by the National Development and Reform Commission, Ministry of Foreign Affairs and Ministry of Commerce of the People's Republic of China, with State Council authorization, Xinhuanet, http://news.xinhuanet.com/english/china/2015-03/28/c_134105858.htm;

Weidenbaum, M.L., Hughes, S. 1996. The Bamboo Network: How Expatriate Chinese Entrepreneurs are Creating a New Economic Superpower in Asia, Simon and Schuster. 